\title{
Implementasi Metode Critical Path Method Pada Proyek Synthesis Residence Kemang
}

\author{
S. Ulfa dan E. Suhendar
}

\begin{abstract}
Abstrak - Proyek Synthesis Residence Kemang adalah salah satu proyek yang dikembangkan oleh Synthesis Development. Penelitian yang di lakukan adalah penelitian terhadap kasus penjadwalan proyek Synthesis Residence Kemang pada pekerjaan struktur bawah. Tujuan penelitian ini adalah untuk mengetahui jaringan kerja atau network jalur kritis, mengetahui waktu yang optimal, serta menganalisis perkiraan total biaya pada proyek Synthesis Residence Kemang dengan menggunakan metode CPM (Critical Path Method). Dengan menggunakan Critical Path Method (CPM) didapatkan pekerjaan yang berada di lintasan kritis, diantaranya: Pekerjaan Galian Tanah Basement, Pekerjaan Raft Foundation Tower 2, dan Pekerjaan Retaining Wall Tower 2. Hasil perhitungan dengan metode CPM membutuhkan waktu 369 hari dengan biaya Rp. 62.852.324.528,- dari jadwal yang di tentukan yaitu 484 hari dengan biaya Rp. 62.110.831.400,-.
\end{abstract}

Kata Kunci- Manajemen Proyek, Critical Path, Network Diagram, Crash Program, Cost Slope

\begin{abstract}
The Synthesis Residence Kemang Project is one of the projects developed by Synthesis Development. The research that was carried out was a study of the scheduling of the Synthesis Residence Kemang project on the lower structural work. The purpose of this study was to find out the network or network critical path, find out the optimal time, and analyze the estimated total cost of the Synthesis Residence Kemang project using the CPM (Critical Path Method) method. By using the Critical Path Method (CPM), it is found that the work is on the critical track, including: Ground Basement Excavation Work, Raft Foundation Tower 2 Work, and Retaining Wall Tower Work 2. The calculation results using the CPM method take 369 days at a cost of Rp. 62,852,324,528,- from the specified schedule which is 484 days at a cost of Rp. 62,110,831,400,-.
\end{abstract}

Keywords - Project Management, Critical Path, Network Diagram, Crash Program, Cost Slope.

\section{PENDAHULUAN}

Tndeks Harga Properti Komersial pada triwulan IV2018 triwulanan meningkat sebesar $0,62 \%$ lebih tinggi dibandingkan $0,03 \%$ pada triwulan sebelumnya. Kenaikan harga properti komersial tertinggi terjadi pada convention hall 3,71\% diikuti oleh hotel 3,09\% dan warehouse complex $1,64 \%$. Peningkatan harga pada convention hall dan hotel terutama didorong oleh meningkatnya permintaan untuk kegiatan Meeting, Incentive, Convention, and Exhibition (MICE) di wilayah Jabodetabek[1]. Banyaknya perusahaan developer yang berdiri dan bermunculan membuat banyaknya proyek kontruksi. Proyek yang baik adalah yang selesai tepat waktu meskipun luasnya ruang lingkup dan target yang terbatas.

Dengan luasnya ruang lingkup, dan target yang terbatas dalam pelaksanaan proyek, maka diperlukan manajemen proyek untuk mengatur agar proyek dapat berjalan sesuai dengan target yang di tentukan. Manajemen proyek adalah cara mengontrol, mengorganisir dan mengelola sumber daya maupun penghasilan yang penting untuk menyelesaikan proyek[2]. Untuk itu, diperlukan suatu penjadwalan

Siti Ulfa, Program Studi Teknik Industri, Universitas Indraprasta PGRI, Jakarta (E-Mail: ulfah922@gmail.com)

Endang Suhendar, Program Studi Teknik Industri, Universitas Indraprasta PGRI, Jakarta (E-Mail: endangunindra@gmail.com) proyek yang tepat untuk mengendalikan proyek. Penjadwalan proyek membantu menunjukkan hubungan setiap aktivitas dengan aktivitas lainnya dan terhadap keseluruhan proyek, mengidentifikasi hubungan-hubungan yang harus diselesaikan lebih dahulu diantara aktivitas lainnya. Serta menunjukkan perkiraan waktu yang realistis untuk setiap aktivitas[3].

Dalam penelitian yang sedang dilakukan, sistem penjadwalan proyek Synthesis Residence Kemang mengalami kemunduran dari jadwal yang telah ditentukan yang disebabkan oleh beberapa faktor yaitu keterlambatan pada pekerjaan galian tanah basement disebabkan oleh turunnya hujan yang tak menentu pada bulan Januari tahun 2018. Pada pekerjaan Raft Foundation Tower 2 keterlambatan proyek disebabkan oleh tenaga kerja yang tidak masuk kembali bekerja pada bulan Pebruari tahun 2018 minggu ketiga setelah upah diberikan. Pada pekerjaan Retaining Wall Tower 3 keterlambatan proyek disebabkan oleh mobilisasi kedatangan pengiriman dari supplier material besi on site pada bulan April tahun 2018. Dari kemunduran tersebut akan berdampak pada kerugian biaya dari kontrak yang telah disepakati.

Salah satu metode penjadwalan yang dapat digunakan adalah CPM (Critical Path Method) yang membuat asumsi bahwa waktu aktivitas yang 
diketahui dengan pasti hanya diperlukan satu faktor waktu untuk setiap aktivitasnya. CPM (Critical Path Method) menunjukkan efektivitas dalam perencanaan, penjadwalan, dan pengorganisasian, koordinasi, pengelolaan, dan pengendalian waktu dan biaya proyek[4]. Dari penelitian dengan metode CPM ini diharapkan pada perencanaan penjadwalan pelaksanaan proyek dapat memperoleh waktu dan biaya pelaksanaan proyek yang lebih efisien.

\section{a. Critical Path Method}

Critical Path Method (CPM) adalah teknik menganalisis jaringan kegiatan/aktivitas-aktivitas ketika menjalankan proyek dalam rangka memprediksi durasi total. CPM (Critical Path Method) pada dasarnya adalah merupakan metode yang berorientasi pada waktu, dalam arti bahwa CPM akan berakhir pada penentuan waktu[5]. Metode ini mengidentifikasi jalur kritis pada aktifitas yang ditentukan ketergantungan antar aktifitasnya.

b. Waktu dan Durasi Kegiatan

Dalam konteks penjadwalan, terdapar dua perbedaan, yaitu waktu (time) dan kurun waktu (duration). Bila waktu menyatakan siang atau malam, sedangkan kurun waktu atau durasi menunjukkan lamanya waktu yang dibutuhkan dalam melakukan suatu kegiatan, seperti lamanya waktu kerja dalam satu hari adalah 8 jam[6].

\section{c. Bagan Balok atau Barchart}

Dalam Bar Chart (Bagan Balok), kegiatan digambarkan dengan balok horizontal. Panjang balok menyatakan lama kegiatan dalam skala waktu yang dipilih. Bagan balok terdiri atas sumbu y yang menyatakan kegiatan atau paket kerja dari lingkup proyek dan digambarkan sebagai balok, sedangkan sumbu $\mathrm{x}$ menyatakan satuan waktu dalam hari, minggu, atau bulan sebagai durasinya[7].

\section{d. Metode Penjadwalan Network Planning}

Network Planning pada dasarnya adalah hubungan ketergantungan antara bagian pekerjaan yang digambarkan atau divisualisasikan dalam diagram network[8].

\section{Activity on Node (AON)}

Activity on Node (AON) adalah di mana tanda panah hanya menyatakan keterkaitan antara kegiatan[9]. Kegiatan dari peristiwa pada PDM ditulis dalam bentuk node yang berbentuk kotak segi empat.

\section{Activity On Arrow (AOA)}

Beberapa hal yang digunakan sebagai pedoman dalam pembuatan network diagram adalah sebagai berikut[10]:

a) Dalam penggambaran, network diagram harus jelas dan mudah untuk dibaca.

b) Harus dimulai dari kejadian dan diakhiri pada kejadian.

c) Kegiatan disimbolkan dengan anak panah yang digambar garis lurus dan boleh patah.

d) Dihindari terjadinya perpotongan antara anak panah.

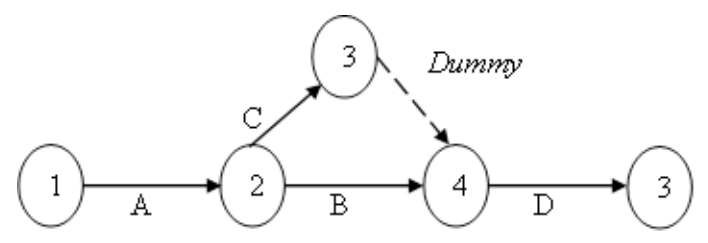

Gambar 1. Network diagram AOA

Untuk membentuk visualisasi dari network planning, perlu digunakan simbolsimbol yaitu:

a) $\longrightarrow$ Arrow (anak panah), menyatakan sebuah kegiatan atau aktivitas yang memerlukan durasi (jangka waktu tertentu).

b) $\mathrm{O} \quad$ Node, merupakan lingkaran yang menyatakan sebuah kegiatan atau peristiwa (event) sebagai awal atau akhir atau pertemuan dari satu atau beberapa kegiatan.

c) $\rightarrow$ Double Arrow, bentuknya merupakan arah panah sejajar, yang menunjukkan kegiatan lintasan kritis (critical path).

d) $\rightarrow$ Dummy, bentuknya merupakan arah panah terputus-putus yang menyatakan kegiatan semu untuk membatasi mulainya kegiatan.

\section{e. Perhitungan Jalur Kritis}

Perhitungan jalur kritis mencakup dua tahap. Tahap pertama disebut perhitungan maju (forward pass), di mana perhitungan dimulai dari node "awal" dan bergerak ke node "akhir" [11]. Di setiap node, sebuah angka dihitung yang mewakili waktu yang tercepat untuk suatu kejadian yang bersangkutan. Tahap kedua yang disebut perhitungan mundur (backward pass), memulai perhitungan dari node "akhir" dan bergerak ke node "awal".

\section{Perhitungan Maju (Forward Pass)}

Forward pass adalah langkah maju untuk menghitung waktu selesai paling awal suatu kegiatan EF (Earliest Finish time). Dengan cara $\mathrm{EF}=\mathrm{ES}+\mathrm{D}$ [7]. Pada perhitungan maju dimaksudkan untuk 
menghitung saat yang paling awal terjadinya dan penyelesaian kegiatan suatu proyek. Waktu mulai paling awal ES (Earliest Start Time).

\section{Perhitungan Mundur (Backward Pass)}

Pada perhitungan mundur dimaksudkan untuk menghitung saat yang paling akhir penyelesaian dan terjadinya dari kegiatan suatu proyek.

\section{f. Crash Program}

Crash program adalah salah satu cara untuk mempercepat waktu penyelesaian proyek, yaitu dengan mereduksi waktu penyelesaian kegiatan yang berada di lintasan kritis yang akan berpengaruh terhadap waktu penyelesaian proyek[12].

\section{METODE DAN PROSEDUR}

\section{a. Metode Pengumpulan Data}

Metode pengumpulan data yang dipergunakan pada penelitian ini adalah wawancara, observasi, dan studi pustaka.

\section{b. Flowchart Penelitian}

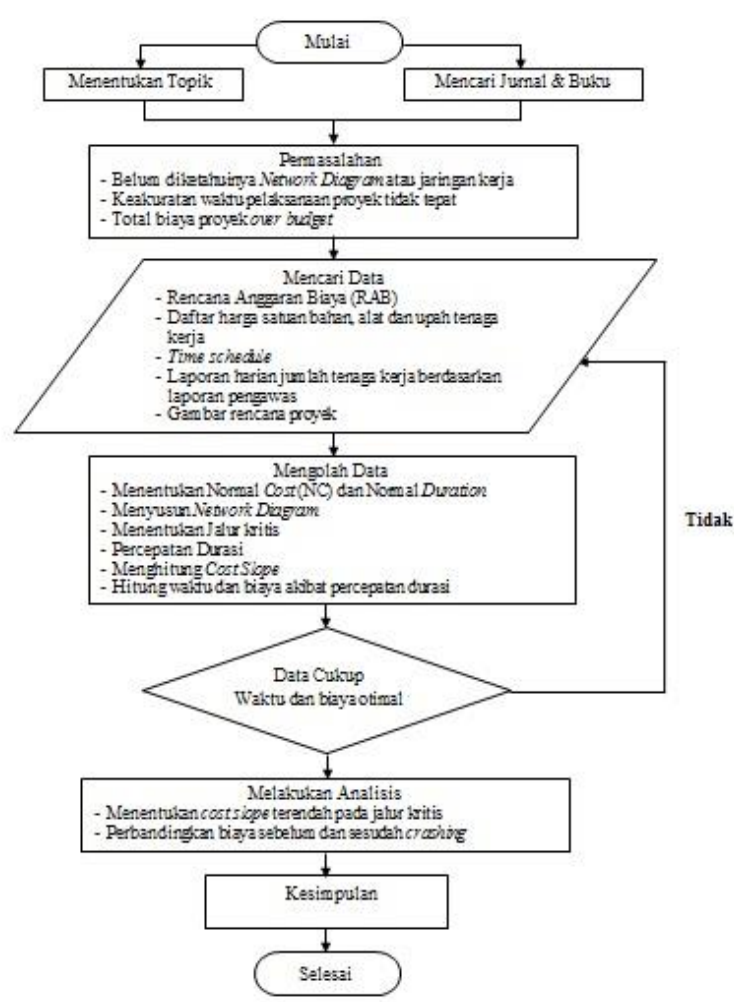

Gambar 2. Flowchart Penelitian

\section{HASIL DAN PEMBAHASAN}

Dalam proses pengerjaan dari awal hingga selesai proyek terdiri dari 7 kegiatan yang saling berhubungan dalam pelaksanaan proyek. Berikut adalah uraian jenis kegiatan dan waktu pelaksanaan proyek Synthesis Residence Kemang pekerjaan struktur bawah.

Tabel 1. Jenis Kegiatan dan Waktu Pelaksanaan Proyek Synthesis Residence Kemang Tahun 2018

\begin{tabular}{clccc}
\hline No. & \multicolumn{1}{c}{ Aktivitas Proyek } & Hari Pekerjaan & $\begin{array}{c}\text { Durasi } \\
\text { Waktu } \\
\text { (dalam } \\
\text { Hari) }\end{array}$ \\
\hline 1. & Pekerjaan Persiapan, Prasarana dan Penunjang & 1 & 60 & 60 \\
\hline 2. & Pekerjaan Capping Beam & 61 & 146 & 86 \\
\hline 3. & Pekerjaan Galian Tanah Basement & 61 & 214 & 154 \\
\hline 4. & Pekerjaan Raft Foundation Tower 3 & 61 & 90 & 30 \\
\hline 5. & Pekerjaan Raft Foundation Tower 2 & 215 & 244 & 30 \\
\hline 6. & Pekerjaan Retaining Wall Tower 3 & 245 & 364 & 120 \\
\hline 7. & Pekerjaan Retaining Wall Tower 2 & 365 & 484 & 120 \\
\hline
\end{tabular}

Pada tabel 1. dapat dilihat secara lengkap aktivitas kegiatan proyek yang dilakukan dalam proses pekerjaan struktur pada proyek Synthesis Residence Kemang. Durasi total proyek pekerjaan struktur adalah 484 hari yang mulai dihitung sejak terbitnya surat perintah kerja (SPK), dapat dilihat pada tabel 1 .

a. Perencanaan Proyek

Berdasarkan pengumpulan data yang dilakukan oleh peneliti pada proyek Synthesis Residence Kemang didapatkan biaya proyek menjadi 2 (dua), yaitu: biaya langsung dan biaya tidak langsung.

1. Biaya Langsung

Biaya langsung adalah biaya yang diperlukan untuk dapat berlangsungnya kegiatan fisik proyek yang dapat dibebankan langsung pada masing-masing pekerjaan. Dan biaya yang diperlukan langsung untuk mendapatkan sumber daya yang akan dipergunakan untuk penyelesaian proyek.

Tabel 2. Anggaran Biaya Kegiatan Proyek Synthesis Residence Kemang Tahun 2018

\begin{tabular}{clcccc}
\hline No. & \multicolumn{1}{c}{ Aktivitas Proyek } & Qty & Sat & $\begin{array}{c}\text { Total } \\
\text { Harga }\end{array}$ \\
\hline 1. & Pekerjaan Persiapan, Prasarana dan Penunjang & 1 & lot & Rp. 4.493.210.400,- \\
\hline 2. & Pekerjaan Capping Beam & 1 & lot & Rp. 1.813.740.000,- \\
\hline 3. & Pekerjaan Galian Tanah Basement & 1 & lot & Rp. 9.083.120.200,-- \\
\hline 4. & Pekerjaan Raft Foundation Tower 3 & 1 & lot & Rp. 18.268.755.600,- \\
\hline 5. & Pekerjaan Raft Foundation Tower 2 & 1 & lot & Rp. 18.268.755.600,- \\
\hline 6. & Pekerjaan Retaining Wall Tower 3 & 1 & lot & Rp. 3.032.074.800,- \\
\hline 7. & Pekerjaan Retaining Wall Tower 2 & 1 & lot & Rp. 3.032.074.800,-- \\
\hline & Total & & & Rp. 57.991.731.400,- \\
\hline
\end{tabular}

2. Biaya Tidak LangsungBiaya tidak langsung adalah biaya yang diperlukan pada suatu proyek yang tidak dibebankan langsung ke 
masing-masing pekerjaan agar terlaksananya pelaksanaan proyek ini. Dari total lama pelaksanaan proyek yaitu 484 hari, maka biaya yang tidak langsung penyelesaian proyek ini sebesar Rp. 4.839.100.000,-

b. Total Anggaran Proyek

Total anggaran proyek pada proyek Synthesis Residence Kemang adalah:

Total Biaya Proyek = Biaya Langsung + Biaya Tidak Langsung $=$ Rp. 57.487.731.400,- + Rp. 4.839.100.000,$=$ Rp. 62.326.831.400,-

Penyusunan Jaringan Kerja Pada Metode Critical Path Methode (CPM). Adapun langkahlangkah yang perlu dilakukan dalam membuat jaringan kerja dengan metode CPM, yaitu:

a. Mengidentifikasi Proyek Dalam KegiatanKegiatan

Berikut adalah perincian kegiatan-kegiatan proyek dapat dilihat pada tabel 3 .

Tabel 3. Daftar Urutan Kegiatan

\begin{tabular}{clc}
\hline No. & \multicolumn{1}{c}{ Jenis Kegiatan } & Kode Kegiatan \\
\hline 1. & Pekerjaan Persiapan, Prasarana dan Penunjang & A \\
\hline 2. & Pekerjaan Capping Beam & B \\
\hline 3. & Pekerjaan Galian Tanah Basement & C \\
\hline 4. & Pekerjaan Raft Foundation Tower 3 & D \\
\hline 5. & Pekerjaan Raft Foundation Tower 2 & E \\
\hline 6. & Pekerjaan Retaining Wall Tower 3 & F \\
\hline 7. & Pekerjaan Retaining Wall Tower 2 & G \\
\hline
\end{tabular}

b. Menyusun Hubungan Antar Kegiatan

Dalam menyusun hubungan antar kegiatan ada beberapa kemungkinan yang mungkin terjadi dari hubungan antar kegiatan yang disusun menjadi mata rantai yang sesuai kegiatan dengan ketergantungannya. Berikut adalah beberapa kemungkinan yang akan terjadi yaitu :

1. Suatu kegiatan dapat dikerjakan bersamaan dengan kegiatan lainnya.

2. Suatu kegiatan dapat dikerjakan bila kegiatan yang mendahuluinya telah selesai dikerjakan.

3. Suatu kegiatan dapat dikerjakan secara tersendiri tanpa harus menunggu kegiatan sebelumnya.

Hubungan antar kegiatan pada proyek Synthesis Residence Kemang pekerjaan struktur bawah dapat dilihat pada tabel 4 .

c. Membuat Diagram Network
Pembuatan diagram network ini digambar berdasarkan pada tabel 4. Pada diagram ini dapat dilihat adanya saling ketergantungan antar kegiatan yang dapat dilihat dengan jalur kegiatan, misalnya kegiatan $\mathrm{C}$ yang tidak bisa dilakukan sebelum kegiatan $\mathrm{F}$ dan $\mathrm{G}$ selesai dikerjakan, Diagram Network ini dapat dilihat pada gambar 4.

Tabel 4. Daftar Hubungan antar Kegiatan

\begin{tabular}{clccc}
\hline No. & Jenis Kegiatan & $\begin{array}{c}\text { Kode } \\
\text { Kegiatan }\end{array}$ & $\begin{array}{c}\text { Kegiatan } \\
\text { yang } \\
\text { Mendahului }\end{array}$ & $\begin{array}{c}\text { Durasi } \\
\text { (hari) }\end{array}$ \\
\hline 1. & Pekerjaan Persiapan, Prasarana dan Penunjang & A & - & 60 \\
\hline 2. & Pekerjaan Capping Beam & B & A & 86 \\
\hline 3. & Pekerjaan Galian Tanah Basement & C & A & 154 \\
\hline 4. & Pekerjaan Raft Foundation Tower 3 & D & A & 30 \\
\hline 5. & Pekerjaan Raft Foundation Tower 2 & E & B, C, D & 30 \\
\hline 6. & Pekerjaan Retaining Wall Tower 3 & F & D, E & 120 \\
\hline 7. & Pekerjaan Retaining Wall Tower 2 & G & F & 120 \\
\hline & & & &
\end{tabular}

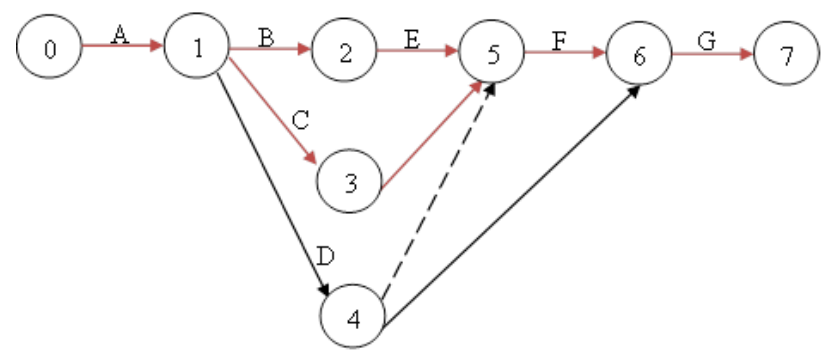

Gambar 3. Network Planning Proyek Synthesis Residence Kemang

d. Menentukan Saat Tercepat Dimulainya Kegiatan Earliest Start (ES) dan Saat Paling Lambat Dimulai Kegiatan Lastest Start (LS)

Tabel 5. Daftar Float dan Kegiatan Kritis

\begin{tabular}{|c|c|c|c|c|c|c|c|c|}
\hline \multirow[b]{2}{*}{ No. } & \multirow[t]{2}{*}{$\begin{array}{c}\text { Kode } \\
\text { Kegiatan }\end{array}$} & \multirow[t]{2}{*}{$\begin{array}{c}\text { Durasi } \\
\text { (hari) }\end{array}$} & \multicolumn{2}{|c|}{$\begin{array}{c}\text { Perhitungan } \\
\text { Maju }\end{array}$} & \multicolumn{2}{|c|}{ Perhitungan Mundur } & \multirow[b]{2}{*}{$\begin{array}{c}\text { Total Float } \\
\text { (LS-ES) }\end{array}$} & \multirow{2}{*}{$\begin{array}{c}\text { On } \\
\text { Critical } \\
\text { Path }\end{array}$} \\
\hline & & & $\begin{array}{c}\text { ES } \\
\text { Earliest } \\
\text { Start }\end{array}$ & $\begin{array}{c}\text { EF } \\
\text { Earliest } \\
\text { Finish }\end{array}$ & $\begin{array}{c}\text { LS } \\
\text { Lastest } \\
\text { Start }\end{array}$ & $\begin{array}{c}\text { LF } \\
\text { Lastest } \\
\text { Finish }\end{array}$ & & \\
\hline 1. & $\mathrm{~A}$ & 60 & 0 & 60 & 0 & 60 & 0 & ya \\
\hline 2. & B & 86 & 60 & 146 & 128 & 214 & 68 & tidak \\
\hline 3. & $\mathrm{C}$ & 154 & 60 & 214 & 60 & 214 & 0 & ya \\
\hline 4. & $\mathrm{D}$ & 30 & 60 & 90 & 184 & 214 & 124 & tidak \\
\hline 5. & $\mathrm{E}$ & 30 & 214 & 244 & 214 & 244 & 0 & ya \\
\hline 6. & $\mathrm{~F}$ & 120 & 235 & 355 & 244 & 364 & 0 & ya \\
\hline 7. & G & 120 & 256 & 484 & 364 & 484 & 0 & ya \\
\hline
\end{tabular}

Berdasarkan tabel 5 dapat dilihat bahwa jumlah total float dari kegiatan mana saja yang termasuk dalam kegiatan kritis. Kegiatan yang memiliki total float sama dengan nol (0) dan menjadi rangkaian lintasan kritis yaitu kegiatan: A,C,E,F,G. Kegiatan yang memiliki float terdapat tenggang waktu kegiatan yang menentukan bahwa kegiatan tersebut bukan 
termasuk ke dalam lintasan kritis pada proyek ini, yaitu pada kegiatan B dan D atau pekerjaan capping beam dan pekerjan Raft Foundation Tower 3. Pada proyek ini terdapat dua pilihan lintasan kritis. Untuk lebih jelas dapat dilihat dalam bentuk gambar diagram network yang menjadi lintasan kritis adalah A, B, F, E, G dan A, C, E, F, G yang ditandai dengan warna merah untuk jalur kritis pada gambar 4.2.

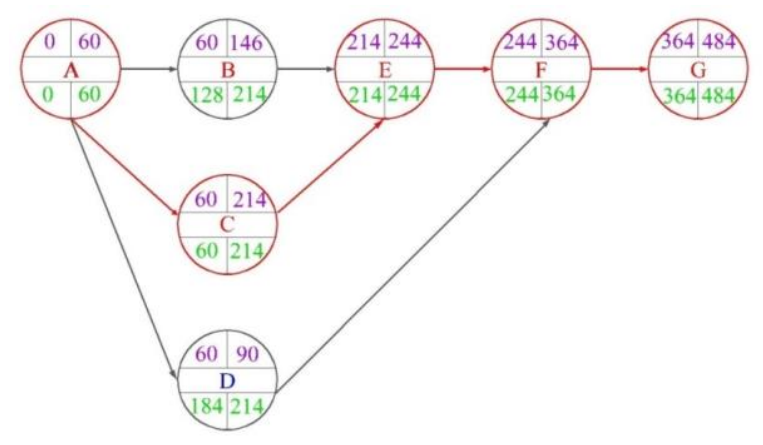

Gambar 4. Jalur Kritis Proyek Synthesis Residence Kemang

e. Perhitungan Percepatan dan Penambahan Biaya (Cost Slope)

Setelah kegiatan kritis dan Cost Slope setiap kegiatan kritis diketahui didapatkan durasi percepatan proyek yang telah disesuaikan dengan hasil lintasan kritis. Hasil perhitungan biaya langsung setelah dipercepat pada kegiatan kritis bisa dilihat pada tabel 6 .

Tabel 6. Hasil Perhitungan Biaya ProyekSetelah Percepatan (dalam satuan Rupiah)

\begin{tabular}{llccccc}
\hline No. & \multicolumn{1}{c}{ Aktivitas Proyek } & $\begin{array}{c}\text { Durasi } \\
\text { Normal } \\
\text { (hari) }\end{array}$ & Biaya Normal & $\begin{array}{c}\text { Durasi } \\
\text { Setelah } \\
\text { Dipercepat } \\
\text { (Hari) }\end{array}$ & $\begin{array}{c}\text { Biaya Setelah } \\
\text { Dipercepat }\end{array}$ & $\begin{array}{c}\text { Cost Slope } \\
\text { Per Hari }\end{array}$ \\
\hline 1. & Pekerjaan Persiapan, Prasarana dan & 60 & 4.493 .210 .400 & 60 & 4.493 .210 .400 & - \\
\hline 2. & Penunjang & 86 & 1.813 .740 .000 & 86 & 1.813 .740 .000 & - \\
\hline 3. & Pekerjaan Capping Beam Galian Tanah Basement & 154 & 9.083 .120 .200 & 96 & 9.208 .282 .800 & 2.157 .976 \\
\hline 4. & Pekerjaan Raft Foundation Tower 3 & 30 & 18.268 .755 .600 & 30 & 18.268 .755 .600 & - \\
\hline 5. & Pekerjaan Raft Foundation Tower 2 & 30 & 18.268 .755 .600 & 19 & 18.810 .144 .305 & 49.217 .155 \\
\hline 6. & Pekerjaan Retaining Wall Tower 3 & 120 & 2.672 .074 .800 & 74 & 2.747 .016 .623 & 1.629 .170 \\
\hline 7. & Pekerjaan Retaining Wall Tower 2 & 120 & 2.672 .074 .800 & 120 & 2.672 .074 .800 & - \\
\hline & Total & & $\mathbf{5 7 . 2 7 1 . 7 3 1 . 4 0 0}$ & & $\mathbf{5 8 . 0 1 3 . 2 2 4 . 5 2 8}$ & \\
\hline & & & & & &
\end{tabular}

f. Analisis Waktu dan Biaya

Perencanaan waktu dan biaya yang dilakukan pada proyek Synthesis Residence Kemang ini dengan durasi normal 484 hari adalah sebagai berikut:

Total Biaya Proyek = Biaya Langsung + Biaya Tidak Langsung $=$ Rp. 57.271.731.400,- + Rp. 4.839.100.000, $=$ Rp. 62.110.831.400,-
Namun setelah dilakukan penelitian dengan menggunakan metode Critical Path Methode (CPM) didapatkan durasi percepatan proyek menjadi 74 hari dengan perhitungan total anggaran sebagai berikut :

Total Biaya Proyek = Biaya Langsung + Biaya Tidak Langsung

$=$ Rp. 58.013.224.528,- + Rp 4.839.100.000,-

$=$ Rp. 62.852.324.528,-

Berdasarkan perhitungan total biaya proyek percepatan maka terjadi penambahan biaya proyek sebesar Rp. 741.493.128,- dari Rp 62.110.831.400,menjadi Rp 62.852.324.528,- untuk mempercepat waktu proyek sebanyak 115 hari dari 484 hari menjadi 369 hari dengan mempercepat waktu penyelesaian proyek diharapkan tidak akan ada lagi terjadinya keterlambatan penyelesaian proyek seperti proyek yang sebelumnya.

\section{KESIMPULAN}

a. Dalam penelitian ini untuk penjadwalan pada proyek Synthesis Residence Kemang ditemukan 2 jalur kritis, jalur 1 yaitu A-B-E-F-G : Pekerjaan Persiapan dan Prasarana Penunjang - Pekerjaan Capping Beam - Pekerjaan Raft Foundation Tower 2 - Pekerjaan Retaining Wall Tower 3 Pekerjaan Retaining Wall Tower 3, sedangkan jalur 2 yaitu dan A-C-E-F-G : Pekerjaan Persiapan dan Prasarana Penunjang - Pekerjaan Galian Tanah Basament - Pekerjaan Raft Foundation Tower 2 - Pekerjaan Retaining Wall Tower 3 Pekerjaan Retaining Wall Tower 3.

b. Kegiatan yang dikerjakan dalam penyelesaian proyek Synthesis Residence Kemang menghabiskan waktu 484 hari, namun dengan menghitung Eearliest Start, Earliest Finish, Lastest Start, dan Lastest Finish pada metode CPM dan melakukaan perhitungan percepatan waktu proyek dapat diselesaikan lebih awal, yaitu dalam waktu 369 hari.

c. Setelah dilakukan perhitungan percepatan waktu proyek (crash program) dengan memperpanjang waktu kerja (lembur) pada Critical Path Method, hasilnya penyelesaian proyek dapat selesai lebih cepat dengan waktu crash 115 hari dan ada penambahan biaya proyek Rp. 741.493.128,- dari biaya normal dengan waktu normal 369 hari. Hal ini menunjukkan adanya efisiensi waktu tetapi terjadi penambahan biaya. Jadi, total biaya yang dibutuhkan untuk penyelesaian proyek Synthesis Residence Kemang dengan menggunakan metode CPM (Critical Path Method) adalah Rp 62.852.324.528,- dari Rp 62.110.831.400,-. 


\section{UCAPAN TERIMA KASIH}

Penulis mengucapkan terima kasih kepada Bpk. Ahyadi Litono selaku Dept. Head PT Sintesis Kreasi Bersama yang yang telah memberi izin untuk melaksanakan penelitian tugas akhir di perusahaan tersebut. Juga kepada Bapak Marthen Febriano selaku Supervisor serta seluruh rekan staff dan karyawan PT Sintesis Kreasi Bersama yang telah membantu memberikan beberapa dokumen yang diperlukan.

\section{REFERENCES}

[1] B. O. Indonesia, "Perkembangan Properti Komersial (Ppkom)."

[2] Hermanto, dkk. (2017). Analisa Network Planning dengan Critical Path Method Pada Proyek Uninteratuble Power Supply 80 kva pada PT Harmon Mitra Sukses (Studi Kasus RSAB Harapan Kita, Jakarta). Jurnal Teknik Universitas Muhammadiyah Tangerang, Vol. 06, No. 01.

[3] Purhariani, Y. (2017). Penerapan CPM (Critical Path Method) dalam Pembangunan Rumah (Studi Kasus Pembangunan Rumah Tipe 36 Ukuran 6 M X 6 M di Jalan Balowerti Nomor 37 Kecamatan Kota Kota Kediri). Simki-Economic. Vol. 01, No. 03.

[4] Aliyu, A. (2013). Project Management Using Critical Path Method (CPM): A Pragmatic Study," Glob. J. Pure Appl. Sci., Vol. 18, No. 3-4.

[5] Nalhadi, A., \& Suntana, N. (2018). Analisa Infrastruktur Desa Sukaci-Baros Dengan Metode Critical Path Method (Cpm). J. Sist. Dan Manaj. Ind., Vol. 1, No. 1, P. 35.

[6] Husen, A. (2010). Manajemen Proyek (Perencanaan, Penjadwalan, dan Pengendalian Proyek). Serpong: Andi.

[7] Iwawo, E. R. M., dkk. (2016). Penerapan Metode Cpm Pada Proyek Konstruksi (Studi Kasus Pembangunan Gedung Baru Kompleks Eben Haezar Manado). Jurnal Sipil Statik, Vol. 4, No. 9, Pp. 551-558.

[8] Qomariyah, S., \& Hamzah, F. ((2013). Analisis Network Planning dengan CPM (Critical Path Method) dalam Rangka Efisiensi Waktu dan Biaya Proyek. e-Jurnal Matriks Teknik Sipil. Vol. 1, No. 4, hal: 408-416.

[9] Walangitan, R., \& Tjakra, J. (2017). Sistem Pengendalian Waktu Dengan Critical Path Method (CPM) Pada Proyek Kontruksi (Studi Kasus: Menara Alfa Omega Tomohon). Jurnal Sipil Statik. Vol. 5, No. 6, hal: 363-371.

[10] Perdana, S., \& Rahman, A. (2019). Penerapan Manajemen Proyek Dengan Metode Cpm (Critical Path Method) Pada Proyek Pembangunan SPBE," Amaliah Jurnal Pengabdian Kepada Masyarakat, Vol. 3, No. 1, Pp. 242-250.

[11] Aulady, M. F. N., \& Orleans, C. (2018). Perbandingan Durasi Waktu Proyek Konstruksi antara Metode Critical Path Method (CPM) dengan Metode Critical Chain Project
Management (Studi Kasus: Proyek Pembangunan Apartamen Menara Rungkut). Jurnal Iptek, Vol. 20, No. 1, P. 13, Apr.

[12] Stefanus, Y. (2017). Analisis Percepatan Waktu Penyelesaian Proyek Menggunakan Metode FastTrack dan Crash Program. Jurnal Media Teknik Sipil, Vol. 15, No. 1. 